\title{
Management of Periapical abscess with Jalaukavcharana (leech application) -A single case study
}

Dr. Sawant Deepak P. ${ }^{1^{*}}$ Dr. Panzade S.M. ${ }^{2}$

Prof. and Head ${ }^{1^{*}}$ Associate Professor ${ }^{2}$ Dept. of Shalakya tantra, Govt. Ayurved

Mahavidyalaya, Osmanabad, Maharashtra, India

*Corresponding author: email: deepakpsawant9@gmail.com Mob: 09422436590

\begin{abstract}
:
In periapical abscess treatment option is incision and drainage (I\&D) and further post operative antibiotics. The healing of post operative wound is tidies because the food particle may lodge in wound which leads to re infection. So without surgical management with we are planned to manage that case with Jalaukavacharan. Jalaukavacharan is indicated in Vranashotha and advised exclusively in delicate patients for Raktamokshan (blood letting). In this case report a female patient of Pitta-kaphaj Prakruti suffering from periapical abscess due to dental carries was treated with Jalaukavacharan (leech application at cheek) in five sittings weekly once. The patient was cured completely without any untoward effect. Hence this case highlighted that Jalaukavacharan is effective remedy for management of periapical abscess.
\end{abstract}

Key words: Jalauka, Jalaukavacharan, Dental carries, periapical abscess, Vranashotha

\section{Introduction:}

Dantavidradhi is the disease of Dantamansa having involvement of Tridosha and Rakta. ${ }^{[1]}$ The symptoms of Dantavidradhi are shopha, Ruja and Daha at local site. ${ }^{[2]}$ Yogaratnakar mentioned the management of Dnatagata and Dantamansagat Vyadhi should be treated with raktamokshan. ${ }^{[3]}$ The Raktamokshan can be done with various means that are Jalauka, Shringa, Alabu, Sirvedha. Leech are used for treatment since ancient times for many illness and diseases through blood letting, a method where blood was drawn out in hope that removing impure blood it has many healing effect on human body. There are many species of leeches but only 15 species are used medically. The leeches used in human being are classified as hirudo medicinal or medicinal leeches.

In periapical abscess treatment option is incision and drainage (I \& D) and further post operative antibiotics. The healing of post operative wound is tidies because the food particle may lodge in wound which leads to re infection. So without surgical management with we are planned to manage that case with Jalaukavacharan.

\section{Case History:}

A female patient of aged 26 years visited to Shalakya OPD of Govt. Ayurved Hospital, Osmanabad, Maharashtra with 
complaints of swelling at left molar region, tooth ache since one month. On local examination it was found that the swelling on left cheek was remarkable having measurement $(13 \mathrm{~cm} \times 7 \mathrm{~cm})$ as compare to normal right cheek $(10 \mathrm{~cm} \mathrm{x} 4 \mathrm{~cm})$. During oral finding it was noticed that dental carries was present in $7^{\text {th }}$ molar of left lower jaw. On the basis of complaints and clinical findings diagnosis was made as periapical abscess.

\section{Methodology of Leech application:}

In vitals patient's pulse (74) and BP (130/80 $\mathrm{mm}$ of $\mathrm{Hg}$ ) was measures before application of leech. Total five sittings of leech application were done (Figure 1-5). Every time one leech was applied and approx 3-5-ml blood was noted by sucking of leech. Measurement of cheek was taken during every sitting and found reduction in size as shown in table-1. The symptomatic relief was found after every sitting and patient completely cured after $5^{\text {th }}$ week (Figure-6). During the whole course of treatment no any analgesic and antibiotics were prescribed. Pulse was remained in the range of 70-80 per minute during the treatment of leech application. The BP of patient was measure every time before application of leech which was in the range of $130 / 80 \mathrm{~mm}$ of $\mathrm{Hg}$ to $140 / 90 \mathrm{~mm}$ of $\mathrm{Hg}$.

\section{Images of leech application:}

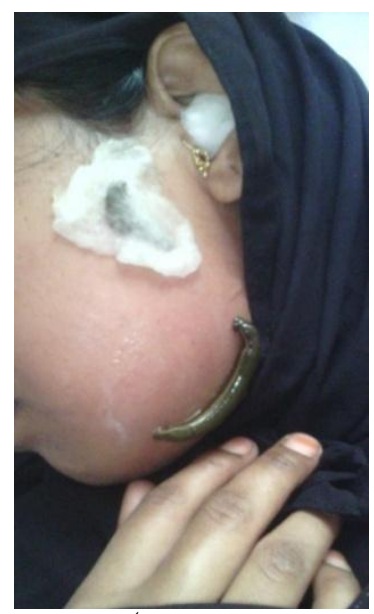

Fig-1: $1^{\text {st }}$ sitting of leech application

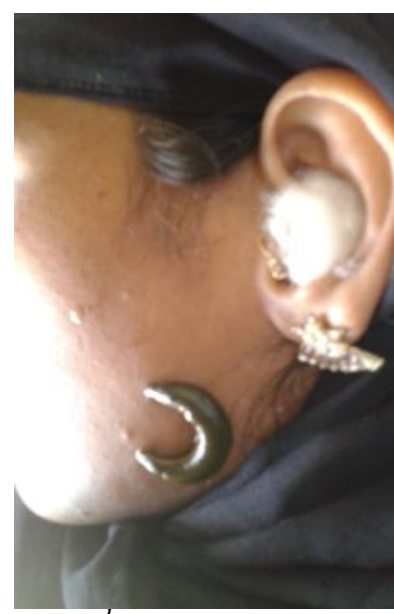

Fig-2: $2^{\text {nd }}$ sitting of leech application

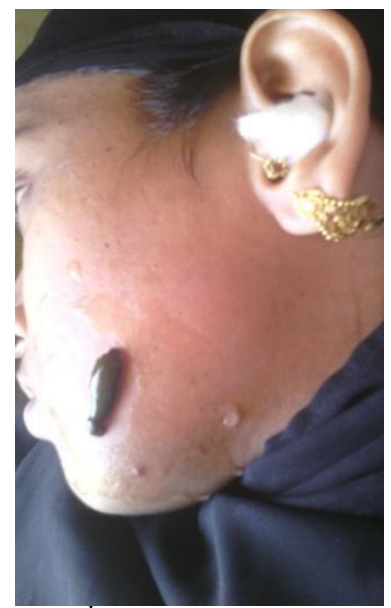

Fig-3: $3^{\text {rd }}$ sitting of leech application 


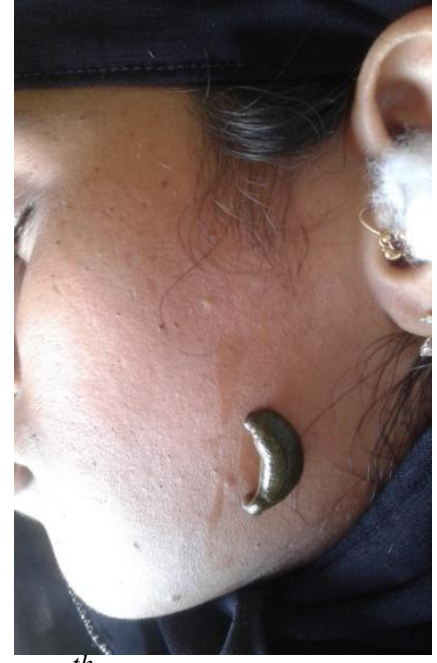

Fig-4:4 $4^{\text {th }}$ sitting of leech application

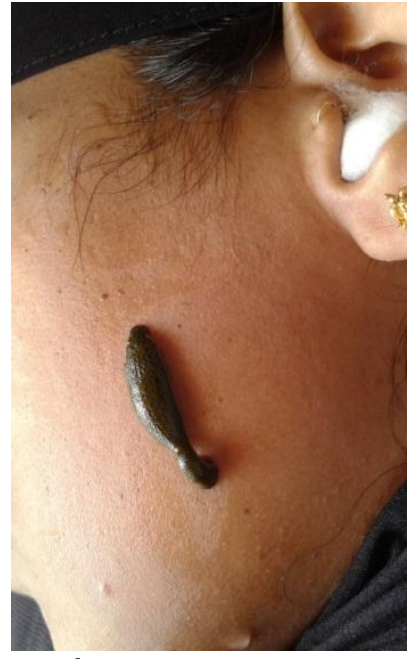

Fig-5: $5^{\text {th }}$ sitting of leech application

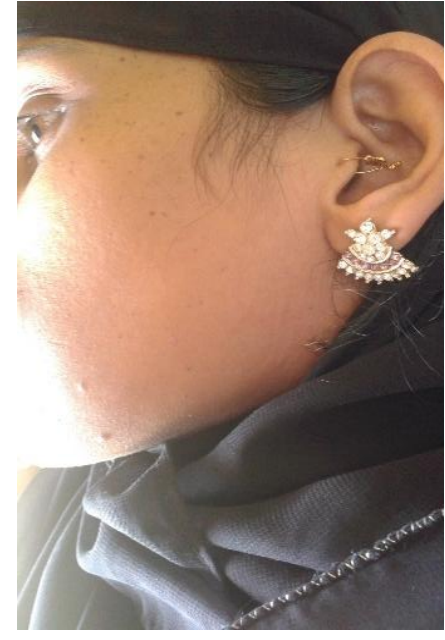

Fig-6:Complete recovery

Table-1: Symptomatic relief in complaints:

\begin{tabular}{|l|l|l|l|l|l|}
\hline Symptoms & $\mathbf{1}^{\text {st }}$ setting & $\mathbf{2}^{\text {nd }}$ setting & $\mathbf{3}^{\text {rd }}$ setting & $\mathbf{4}^{\text {th }}$ setting & $\mathbf{5}^{\text {th }}$ setting \\
\hline Swelling & $13 \times 7$ & $11 \times 5$ & $10.5 \times 4.5$ & $10.2 \times 4$ & $10.1 \times 4$ \\
\hline Pain (VAS $*$ ) & 8 & 6 & 3 & 1 & 0 \\
\hline Tenderness & present & present & absent & absent & absent \\
\hline
\end{tabular}

*VAS: Visual Analog Scale [(scale 0-10)

\section{Result and Discussion:}

The saliva of leech contains the hirudin which is anti-coagulant and inhibits the coagulation of blood. Another compound is calin which inhibit the platelet aggregation caused by collagen. ${ }^{[4]}$ The action of destabliase is to break up any fibrins which also have thrombolytic effects that dissolve clots of blood. Because of anticoagulation agents, the blood becomes thinner allowing flowing freely through the vessels. This normal circulation helped to heal the tissue. Bdellins is a compound in the leech's saliva that acts as an anti inflammatory agent by inhibiting trypsin as well as plasmin. ${ }^{[5]}$ This helped in reducing the
$0=$ no pain and $10=$ severe and unbearable pain $]$

swelling and congestion of tissue in this case. Another anti inflammatory agent is the Eglins which help to reduce the inflammation. There are three compounds in leech`s saliva that act as a vasodilator agent, and they are the histamine -like substances, the actelycholine and the carboxypeptidase. ${ }^{[6]}$ Due to this action vessels are dilated and allow to reach blood supply and nutrition to the disease tissue allow to relief in symptoms. The saliva of leeches also contains anesthetic substance which relieves the pain on the site and also bacteria inhibiting substances which inhibit the growth of bacteria at affected site. ${ }^{[7]}$ Hence the infection controlled and stops further growth of 
bacteria and help to relief the symptoms.

\section{Conclusion:}

On the basis of this single case study it can be concluded that the Jalaukavcharan (leech application) is non pharmacological and para-surgical treatment is effective in delicate and female patients of periapical abscess. This is a single case report and for its scientific validation it requires to be tried in more number of patients.

Acknowledgement: Author acknowledge to Prof. Prakash Khaparde, Dean, Govt. Ayurved Mahavidyalaya, Osmanabad for providing all facilities in the hospital.

\section{References:}

1. Atridev Gupta, Vagbhata' Asthang Samgraha vol-2, Chaukhambha Krishnadas Academy, Varanasi 2005 p.277.
2. Ambika Dutta Shastri, Sushrut Samhita, AyurvedTattvaSandipak, (Hindi translation ) Vol- 1, Chaukhambha Sanskrit Sansthan, Varanasi 2005 p-72

3. Lakshmipati Shastri, Yogratnakara Chaukhambha Prakashan, Varanasi $3^{\text {rd }}$ ed. 1983 p- 298

4. Munro R, Jones CP, Sawyer RT. Calin-a platelet adhesion inhibitor from the saliva of the medicinal leech. Blood Coagul Fibrinolysis. 1991;2(1):179-84.

5. http://www.naturheilpraxis-potsdamerplatz.com/en/medicinal-leech-therapyberlin.html accessed on 10.09.2017

6. Kellogg DL Jr, Zhao JL, Coey U, Green JV. Acetylcholine-induced vasodilation is mediated by nitric oxide and prostaglandins in human skin. $\mathrm{J}$ Appl Physiol. 2005;98(2):629-32.

7. http://www.leechestherapy.com/aboutleeches/benefits 'Treating gum disease' accessed on 10.09.2017.

Guarantor: Corresponding author is guarantor of this article and its contents.

Conflict of interest: Author declare that there is no conflict of interest

\section{How to cite this article:}

Sawant DP and Panzade SM. Management of periapical abscess with Jalaukavcharana (Leech application) - A single case study Int. J. AYUSH CaRe. 2017;1(1):6-9. 